\title{
PLASMA VITAMIN D STATUS AND ASSOCIATED FACTORS AMONG PREGNANT WOMEN OF PESHAWAR, KHYBER PAKHTUNKHAWA, PAKISTAN: A PILOT STUDY
}

\author{
Babar Shahzad', Muhammad Shahzad ${ }^{1 \otimes}$, \\ Muhammad Jaffar Khan'†, Sarah Khan', Hafia Bibi'
}

\begin{abstract}
OBJECTIVE: To assess plasma vitamin $\mathrm{D}$ status and its association with dietary intake and body mass index (BMI) in primary gravida women.

METHODS: This cross-sectional study was carried out in the Department of Gynecology, Lady Reading Hospital (LRH) and Institute of Basic Medical Sciences, Khyber Medical University, Peshawar from January to March 2016. Primary gravida women $(n=88)$ in their first trimester attending antenatal clinic at LRH were included. Socio-demographic and anthropometric measures were recorded using standard methods. Nutritional intake was assessed using 24-hours dietary recall. Blood samples were collected to assess plasma vitamin D status through ELISA.
\end{abstract}

RESULTS: Median plasma $25-\mathrm{OH}$ vitamin D levels were $41.71 \mathrm{\eta g} / \mathrm{mL}$ $(\mathrm{IQR}=17.29)$. Only 8 (9.09\%) women had vitamin D deficiency $(<15 \eta \mathrm{g} / \mathrm{mL}), 10$ (II.36\%) had insufficiency $(15-30 \mathrm{ng} / \mathrm{mL})$ and $70(79.54 \%)$ had adequate $(>30$ $\eta \mathrm{g} / \mathrm{mL}$ ) levels of plasma vitamin $\mathrm{D}$. Dietary intake of vitamin $A$ and thiamine were significantly different between the three groups (sufficient/insufficient/deficient). No significant correlation was found between plasma vitamin $D$ and anthropometric and dietary variables. Only socioeconomic status $(p=0.03)$ was significantly associated with plasma vitamin $D$ status.

CONCLUSION: In our study, plasma vitamin D status was not significantly associated with dietary intake and BMI in primary gravida women. However, due to relatively small sample size, results may be taken with caution and large-scale study is recommended to establish the relationship of plasma vitamin $D$ status with dietary intake and BMI in antenatal women.

KEYWORDS: Vitamin D (MeSH); Body Mass Index (MeSH); Dietary intake (Non$\mathrm{MeSH})$; Pregnancy (MeSH); Gravidity (MeSH); Diet Record (MeSH); Adult (MeSH); Female (MeSH).; Blood Glucose (MeSH); Insulin (MeSH); Glutathione Peroxidase $(\mathrm{MeSH})$.

THIS ARTICLE MAY BE CITED AS: Shahzad B, Shahzad M, Khan MJ, Khan S, Bibi H. Plasma vitamin D status and associated factors among pregnant women of Peshawar, Khyber Pakhtunkhawa, Pakistan: a pilot study. Khyber Med Univ J 20 I 9; I I (4):226-30. DOI: 10.35845/kmuj.2019.19274

\section{INTRODUCTION}

Viveng itamin D (calciferol) is a fat-soluble vitamin found in human body in either the form of ergocalciferol (vitamin $D_{2}$ ) or cholecalciferol (vitamin $D_{3}$ ). Vitamin $D$ is unique vitamin in a sense that it's synthesis in the body occurs through exposure of the skin to ultraviolet-B (UV-B) radiations of the sun. These radiations penetrate the skin and convert 7-dehydrocholesterol into pre-vitamin $D_{3}$ that is subsequently converted into vitamin $D_{3}$ in the liver.'
Food sources of vitamin D are very few such as oily fish, cod liver oil, butter and eggs. ${ }^{2}$ The recommended dietary allowance of vitamin D is $600 \mathrm{IU} /$ day for adult male and female. ${ }^{2}$

Vitamin $D$ is classically known for its role in bone mineralization through absorption and homeostasis of calcium and phosphorus. ${ }^{3}$ In the body, it does so by increasing calcium channels and the expression of calcium binding protein in the small intestine. ${ }^{4}$ Vitamin $D$ also
I. Institute of Basic Medical Sciences, Khyber Medical University, Peshawar, Pakistan. Email『: drshahzad.kmu@gmail.com Contact\#: +92-345-9048796 †Died: July 18, 2019

$\begin{array}{ll}\text { Date Submitted: } & \text { May 04, 2019 } \\ \text { Date Revised: } & \text { November 17, 2019 } \\ \text { Date Accepted: } & \text { November 17, 2019 }\end{array}$

increases cell maturation and apoptosis and decreases cell proliferation. ${ }^{5}$ Furthermore, it also regulates insulin secretion and protect against renal diseases by suppressing inflammation, inhibiting rennin-angiotensin-aldosterone system and restoring glomerular filtration barrier. ${ }^{6}$ Deficiency of vitamin D mainly causes rickets in children and osteomalacia in adults. ${ }^{7}$ Vitamin D deficiency has been implicated in obesity, decreased insulin sensitivity, increased risk for developing the metabolic syndrome, nonspecific musculoskeletal pain, autoimmune diseases, cardiovascular disease and cancer. ${ }^{2}$ Furthermore, deficiency of vitamin $D$ during pregnancy can also result can increase the risk for preeclampsia in women ${ }^{8,9}$ and rickets in infants. ${ }^{10,11}$

Vitamin D deficiency is a major public health problem in many countries of the world. It is estimated that approximately I $5 \%$ of the global population (around one billion people) have vitamin $\mathrm{D}$ deficiency $(<20 \mathrm{ng} / \mathrm{mL})$ or insufficiency (20 $30 \mathrm{ng} / \mathrm{mL}$ ). ${ }^{12}$ The problem is more evident and issue of public health concerns in low and middle income countries $\left(\right.$ LMIC) ${ }^{13}$ including South Asian countries such as India, ${ }^{14}$ Bangladesh ${ }^{15}$ and Afghanistan. ${ }^{16}$ Similarly, according to National Nutrition Survey of Pakistan (NNS 20II), approximately $68.8 \%$ women were found to be vitamin $D$ deficient $(<30 \eta \mathrm{ng} / \mathrm{mL})$. $^{17}$ These figures were also reflected at provincial levels in Khyber Pakhtunkhwa where prevalence of vitamin $D$ deficiency is approximately $64 \%$ in women. Other studies from Pakistan have also reported vitamin D deficiency in different populations. ${ }^{18,19}$ Previously, studies in different populations revealed that plasma vitamin $D$ status during pregnancy also depends on nutritional intake/status, ${ }^{20}$ multiparity ${ }^{21}$ and stage of pregnancy. ${ }^{22}$ However, to the best of our knowledge, no such studies are conducted in our local population so far. Therefore, this study aimed to investigate plasma vitamin $D$ status and its 
TABLE I: BASIC DEMOGRAPHIC AND ANTHROPOMETRIC DATA OF THE STUDY PARTICIPANTS $(n=88)$

\begin{tabular}{|l|c|c|c|}
\hline Variable & Median & QI, Q3 & IQR \\
\hline Age (years) & 20.00 & $18.0,23.0$ & 5.000 \\
\hline Years of Marriage & 0.850 & $0.5,1.900$ & 1.400 \\
\hline Family Size $(\mathrm{n})$ & 8.000 & $6.0,12.00$ & 6.000 \\
\hline Systolic BP $(\mathrm{mm} \mathrm{Hg})$ & 110.00 & $100.0,110.00$ & 10.00 \\
\hline Diastolic BP $(\mathrm{mm} \mathrm{Hg})$ & 70.00 & $60.0,80.00$ & 20.00 \\
\hline Height $(\mathrm{cm})$ & 155.15 & $151.9,159.02$ & 7.17 \\
\hline Height $(\mathrm{m})$ & 1.5530 & $1.5,1.5902$ & 0.0702 \\
\hline Weight $(\mathrm{kg})$ & 54.500 & $48.9,61.375$ & 12.450 \\
\hline Body Mass Index $\left(\mathrm{kg} / \mathrm{m}^{2}\right)$ & 22.221 & $20.5,24.752$ & 4.277 \\
\hline
\end{tabular}

TABLE II: BASIC DEMOGRAPHIC AND SOCIOECONOMIC STATUS DATA OF STUDY PARTICIPANTS

\begin{tabular}{|l|l|c|c|}
\hline \multicolumn{2}{|l|}{ Variable } & Frequency & Percentage \\
\hline \multirow{4}{*}{ Socioeconomic status } & High & I & I.I4 \\
\cline { 2 - 4 } & Middle & $3 \mathrm{I}$ & 35.23 \\
\cline { 2 - 4 } & Low & 56 & 63.64 \\
\hline \multirow{4}{*}{ Education } & Higher Education & $\mathrm{II}$ & 12.50 \\
\cline { 2 - 4 } & Higher Secondary & $\mathrm{II}$ & 12.50 \\
\cline { 2 - 4 } & Primary Education & 25 & $28.4 \mathrm{I}$ \\
\cline { 2 - 4 } & Uneducated & $4 \mathrm{I}$ & 46.59 \\
\hline \multirow{3}{*}{ Working status } & House wife & 83 & 94.32 \\
\cline { 2 - 4 } & Working & 5 & 5.68 \\
\hline
\end{tabular}

TABLE III: DIETARY INTAKE OF STUDY PARTICIPANTS MEASURED BY 24-HOURS DIETARY RECALL METHOD

\begin{tabular}{|l|c|c|c|}
\hline Variable & Median & QI, Q3 & IQR \\
\hline Energy $(\mathrm{kJ})$ & 4354 & $3188,56 \mid 3$ & 2425 \\
\hline kcal $(\mathrm{kc})$ & 1032.5 & $753.5,1338.5$ & 585.0 \\
\hline Fat $(\mathrm{g})$ & 40.45 & $23.48,53.27$ & 29.80 \\
\hline Protein $(\mathrm{g})$ & 34.70 & $22.88,50.40$ & 27.52 \\
\hline Carbohydrate $(\mathrm{g})$ & 146.00 & $90.95,187.80$ & 96.85 \\
\hline Thiamine $(\mathrm{mg})$ & 0.7050 & $0.4550,0.9250$ & 0.4700 \\
\hline Riboflavin $(\mathrm{mg})$ & 0.5350 & $0.3100,0.7850$ & 0.4750 \\
\hline Niacin $(\mathrm{mg})$ & 16.350 & $9.450,21.600$ & 12.150 \\
\hline Vitamin B6 $(\mathrm{mg})$ & 0.7250 & $0.4225,1.0375$ & 0.6150 \\
\hline Vitamin BI2 $(\mu \mathrm{g})$ & 0.745 & $0.000,1.555$ & 1.555 \\
\hline Folic acid $(\mu \mathrm{g})$ & 99.50 & $60.00,135.00$ & 75.00 \\
\hline Vitamin C $(\mathrm{mg})$ & 23.30 & $8.90,64.45$ & 55.55 \\
\hline Vitamin $\mathrm{E}(\mathrm{mg})$ & 3.785 & $2.145,5.607$ & 3.462 \\
\hline Vitamin D $(\mu \mathrm{g})$ & 0.4550 & $0.1300,0.9800$ & 0.8500 \\
\hline Vitamin A $(\mu \mathrm{g})$ & 241 & 126,439 & 312 \\
\hline
\end{tabular}

relationship with dietary intake and anthropometric parameters in first trimester of primary gravida women of Peshawar, Pakistan.

\section{METHODS}

This single center, cross-sectional study was carried out in the Department of Gynecology, Lady Reading Hospital and
Institute of Basic Medical Sciences, Khyber Medical University, Peshawar from January to March 2016. Women $(n=88)$ who were apparently healthy, aged I8-40 years, in the first trimester, and having their first pregnancy were included in the study. Those having previous pregnancies (multigravida), severe hyperemesis gravidarum (severe episodes of vomiting), acute or chronic medical condition and those who used antibiotics in the past one month or nutritional supplements in the past 3 months were excluded. The Ethical Review Committee of Khyber Medical University, Peshawar, approved the study.

Socio-demographic characteristics such as age, socioeconomic status and family size of all the participants were recorded. Anthropometric measurements were recorded following standard methods. Height was measured to the nearest 0.1 $\mathrm{cm}$ by using wall mounted Stadiometer (Seca, UK) while the subjects were standing in the Frankfurt plane position. Weight was recorded in kilograms to the nearest $0.1 \mathrm{~kg}$ using calibrated electronic scale (Seca, UK). Body mass index (BMI) was computed as the fraction of weight to the squared height $\left(\mathrm{kg} / \mathrm{m}^{2}\right)$.

Nutritional intake of the participants was assessed by a trained nutritionist using 24hours dietary recall. The 24-hours dietary recall was conducted in the form of an indepth interview using a standardized four stage protocol. ${ }^{23}$ Each participant was asked to provide detailed information about foods and beverages consumed in the past 24 hours. This included the time of day and source of food, portion size of each food and beverage and preparation method were also recorded. Food models and pictures were used to help participants judge and report portion size and improve accuracy.

Blood sample from each participant was collected by a trained phlebotomist in EDTA tubes. At least $10 \mathrm{~mL}$ of blood was collected from each participant in aseptic manner. The samples were then centrifuged for 10 minutes at $4,000 \mathrm{rpm}$ and stored at $-80^{\circ} \mathrm{C}$ till further analysis.

Plasma vitamin $D$ was analyzed through $25-\mathrm{OH}$ vitamin D Diasorin radioimmunoassay ELISA kit (Euroimmun, Germany) following manufacturer instructions. Briefly, stored samples were thawed and mixed thoroughly at room temperature. Around $100 \mu \mathrm{L}$ of the samples and biotinylated working were added to each well of ELISA plate followed incubation for 2 hours at $37^{\circ} \mathrm{C}$. The wells were washed three times with washing buffer followed by addition of chromogenic substrate and incubation. After 30 minutes, the optical density was measured at $450 \mathrm{~nm}$ wavelength through reader microplate reader (Biotek ${ }^{\circledR}$ Elx800). Levels were defined as normal (>30 $\mathrm{ng} / \mathrm{mL})$, insufficient $(15-30 \mathrm{\eta g} / \mathrm{mL})$ or deficient $(<15 \mathrm{ng} / \mathrm{mL})$ as per standard 
TABLE IV: PLASMA 25-OH VITAMIN D STATUS: DEFICIENCY/INSUFFICIENCY/ADEQUACY

\begin{tabular}{|l|c|c|}
\hline Plasma vitamin D levels & Frequency & Percentage \\
\hline Deficient $(<15 \mathrm{\eta g} / \mathrm{mL})$ & 8 & 9.09 \\
\hline Insufficient $(15-30 \mathrm{ng} / \mathrm{mL})$ & 10 & 11.3 \\
\hline Adequate $(>30 \mathrm{ng} / \mathrm{mL})$ & 70 & 79.5 \\
\hline Total & $\mathbf{8 8}$ & 100.0 \\
\hline
\end{tabular}

TABLE V: CORRELATION OF PLASMA VITAMIN D WITH BMI, SYSTOLIC BP, DIASTOLIC BP, HEIGHT, WEIGHT, DIETARY VITAMIN D, FAT AND CARBOHYDRATES

\begin{tabular}{|l|c|c|}
\hline Variable & R Value & P Value \\
\hline Body Mass Index $\left(\mathrm{kg} / \mathrm{m}^{2}\right)$ & 0.06 & 0.54 \\
\hline Systolic BP $(\mathrm{mm} \mathrm{Hg})$ & -0.01 & 0.95 \\
\hline Diastolic BP $(\mathrm{mm} \mathrm{Hg})$ & 0.08 & 0.43 \\
\hline Height $(\mathrm{cm})$ & 0.19 & 0.06 \\
\hline Weight $(\mathrm{kg})$ & 0.01 & 0.96 \\
\hline Dietary vitamin D $(\mathrm{ng})$ & -0.01 & 0.95 \\
\hline Protein $(\mathrm{g})$ & 0.06 & 0.58 \\
\hline Fat $(\mathrm{g})$ & -0.01 & 0.90 \\
\hline Carbohydrate $(\mathrm{g})$ & 0.08 & 0.42 \\
\hline
\end{tabular}

TABLE VI: COMPARISON OF DEMOGRAPHIC, SOCIOECONOMIC, ANTHROPOMETRIC, AND DIETARY DATA BETWEEN PARTICIPANTS

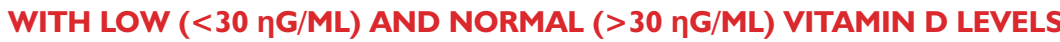

\begin{tabular}{|c|c|c|c|}
\hline Variable & $\begin{array}{c}\text { Low Median } \\
\text { (average Rank) } \\
\text { (<30 } \mathrm{ng} / \mathrm{mL} \text { ) }\end{array}$ & $\begin{array}{c}\text { Normal Median } \\
\text { (average Rank) } \\
\text { (>30 ng/mL) }\end{array}$ & p-value \\
\hline Age (years) & $21.00(44.3)$ & $20.00(44.6)$ & 0.96 \\
\hline Education & $1.000(47.4)$ & $1.000(43.8)$ & 0.56 \\
\hline Years of marriage & $0.7000(42.1)$ & $0.9000(45.1)$ & 0.65 \\
\hline Family Size (n) & $7.500(4 I .4)$ & $8.000(45.3)$ & 0.56 \\
\hline Socioeconomic Status & $1.000(35.8)$ & $1.000(46.8)$ & $0.05 *$ \\
\hline Working/ House wife & $1.000(44.4)$ & $1.000(44.5)$ & 0.97 \\
\hline Systolic BP (mm Hg) & II $10.0(44.1)$ & $110.0(44.6)$ & 0.93 \\
\hline Diastolic BP $(\mathrm{mm} \mathrm{Hg})$ & $70.00(42.2)$ & $70.00(45.1)$ & 0.64 \\
\hline Height $(\mathrm{cm})$ & $156.7(5 \mid .8)$ & $154.9(42.6)$ & 0.17 \\
\hline Weight (kg) & $56.45(47.0)$ & $53.95(43.9)$ & 0.64 \\
\hline $\mathrm{BMI}\left(\mathrm{kg} / \mathrm{m}^{2}\right)$ & $22.26(45.1)$ & $22.15(44.4)$ & 0.91 \\
\hline Vitamin D intake ( $\eta g)$ & $260.0(39.5)$ & $495.0(45.8)$ & 0.35 \\
\hline Energy intake (kJ) & $4 \mid 47(40.3)$ & $4392(45.6)$ & 0.43 \\
\hline Fat $(g)$ & $41.60(42.8)$ & $40.45(44.9)$ & 0.75 \\
\hline Protein $(g)$ & $33.20(40.3)$ & $35.75(45.6)$ & 0.42 \\
\hline Carbohydrate (g) & $99.55(39.1)$ & $147.40(45.9)$ & 0.31 \\
\hline Thiamine $(\mathrm{mg})$ & $0.4900(38.1)$ & $0.7600(46.1)$ & 0.23 \\
\hline Riboflavin (mg) & $0.5400(4 I .5)$ & $0.5350(45.3)$ & 0.58 \\
\hline Niacin (mg) & $14.45(36.9)$ & $16.40(46.5)$ & 0.15 \\
\hline Vitamin B6 (mg) & $0.5650(38.5)$ & $0.7600(46.0)$ & 0.26 \\
\hline Vitamin $\mathrm{B} / 2(\mu \mathrm{g})$ & $0.8700(44.6)$ & $0.7250(44.5)$ & 0.98 \\
\hline Folate $(\mu \mathrm{g})$ & $79.00(39.8)$ & $101.50(45.7)$ & 0.38 \\
\hline Vitamin C (mg) & $21.40(39.4)$ & $24.75(45.8)$ & 0.34 \\
\hline Vitamin E (mg) & $3.295(36.9)$ & $3.785(46.4)$ & 0.15 \\
\hline Vitamin D $(\mu \mathrm{g})$ & $0.2600(39.5)$ & $0.4950(45.8)$ & 0.35 \\
\hline Vitamin $\mathrm{A}(\mu \mathrm{g})$ & $194.0(37.7)$ & $266.5(46.3)$ & 0.20 \\
\hline
\end{tabular}

criteria. $^{24}$

Data was analyzed using Minitab ${ }^{\circledR}$ software Version 17 (Minitab, Inc.). Anderson Darling Normality test was applied to check normality. Data was represented as median and interquartile range. Mann-Whitney $U$ test was used to estimate the difference between two variables. Spearman Rank correlation was used to measure correlation of plasma vitamin $D$ with socio-demographic and anthropometric variables. Kruskall-Wallis test was applied to determine the difference between sufficient, insufficient, and deficient plasma vitamin $D$ levels. Binary logistic regression analysis was used to determine the association of plasma 25$\mathrm{OH}$ vitamin $\mathrm{D}$ (normal/low levels) with age, socioeconomic status, dietary intake and BMI. Results were considered significant where $p$ value was $<0.05$.

\section{RESULTS}

Data regarding demographic, anthropometry and socioeconomic status was collected from all the participants and presented in Table I and II. Median (interquartile range; IQR) age of participants was 20.00 years $(\mathrm{IQR}=5.00)$ and the range was $16-30$ years. Median (IQR) height of participants was $155 \mathrm{~cm}$ $(\mathrm{IQR}=7.17)$ and weight $54.50 \mathrm{~kg}(\mathrm{IQR}=$ 12.450). The median BMI was $22.22 \mathrm{~kg} / \mathrm{m}^{2}$ (4.27) and were normotensive (Table I). Most of the participants $(n=56,63.64 \%)$ were from lower income group uneducated $(n=4 I, 46.59 \%)$ and were house-wives ( $\mathrm{n}=83,94.32 \%)$ (Table II).

Median energy intake was significantly lower than the recommended intake for Pakistani women at this age. The median energy intake of the participants was 4354 (2425) kJ (Table III).

Based on the criteria, of all the participants $(\mathrm{n}=88), 8(\%)$ (Table IV) were vitamin D deficient and I0(\%) (Table II) had insufficiency. Rest of the participants $\mathrm{n}=$ 79,54\%] (Table II) had normal vitamin D status.

Plasma vitamin $D$ was not correlated with any of the anthropometric and dietary variable. Only height showed some tendency of positive correlation $(R=0.19$, $\mathrm{p}=0.06)($ Table V).

When participants were grouped into two groups based on whether they had normal vitamin $D$ levels $(\geq 30 \eta \mathrm{g} / \mathrm{mL}$ ) or low vitamin $D$ levels $(<30 \mathrm{ng} / \mathrm{mL})$, only 
socioeconomic status was marginally significantly different between the two groups $(p=0.05$, Kruskal-Wallis test) (Table IV).

\section{DISCUSSION}

Deficiency of vitamin $D$, the main regulator of the bone mineralization and calcium homeostasis in body is a global public health especially in pregnant women and children. According to estimates, I5-84\% of pregnant women are deficient in vitamin D ("serum 25 $(\mathrm{OH}) \mathrm{D}<25 \mathrm{\eta mol} / \mathrm{L}$ ") thereby increasing the risk of osteomalacia, ${ }^{25}$ intrauterine growth retardation and low birth weight in neonates. ${ }^{26}$ In this pilot study, we have quantitatively assessed vitamins $D$ status of pregnant women in Peshawar and its relationship with dietary intake and sociodemographic and anthropometric characteristics. We have found that majority of pregnant women in the study sample have normal plasma vitamin D status. Furthermore, except socioeconomic status, no significant association was observed between plasma vitamin $D$ status and with dietary intake or BMI. Our results are in conflict with study conducted in India ${ }^{27}$ and other cities of Pakistan (Karachi \& Lahore) who reported that $50-98 \%$ of pregnant women are vitamin $D$ deficient. ${ }^{28,29}$ The conflicting results might be due to the fact that majority of our participants were young, housewives and residing in rural areas. In rural areas of $\mathrm{KP}$, people live in open houses and during daily activities, the women are exposed to sunlight and thus adequate vitamin $D$ is produced in the body. The importance of sunlight exposure in vitamin $D$ synthesis is also confirmed by various studies. ${ }^{30}$ Furthermore, gestational age of the participants and lack of fast foods and carbonated drinks in their diet which negatively impact vitamin $D$ status can be a contributing factor. ${ }^{31}$

In our study, we have observed no significant association between plasma vitamin $D$ status and dietary intake although a study conducted in Karachi on healthy population, showed a significant relationship of vitamin $D$ with dietary intake. ${ }^{32}$ The reason might be that we have collected a dietary intake of only 24 hours which is recall biased and also does not reflect their past dietary intake. Socioeconomic status $(p=0.05)$ was significantly different in low $(<30 \mathrm{~g} / \mathrm{mL})$ and normal $(>30 \mathrm{~g} / \mathrm{mL})$ sub-groups of vitamin $D$ status. Moreover, it was significantly associated $(p=0.03)$ with plasma vitamin $D$ status. Similar result found by a study that high socioeconomic status and working indoor jobs of females are significantly associated with lower vitamin D status.

Our study is unique that we have recruited apparently healthy primary gravida women in their first trimester of pregnancy. However, due to relatively small sample size, we could not observe any significant association with other study variables has certain limitations. Our sample size was relatively small thus did not show any significant relationship between the variables. Therefore, further quantitative studies with a large sample size are required to establish the relationship of plasma vitamin $D$ status with dietary intake and body mass index in antenatal women.

\section{CONCLUSION}

In our study, plasma vitamin D status was not significantly associated with dietary intake and BMI in primary gravida women.

\section{REFERENCES}

I. Nobile S, Tenace MA, Pappa HM. The Role of Vitamin D in the Pathogenesis of Inflammatory Bowel Disease. Gastrointest Disord 2019;1(I):23140. DOI: 10.3390/gidisord I010018.

2. Gangula PR, Dong YL, Al-Hendy A, Richard-Davis G, Montgomery-Rice V, Haddad G, et al. Protective cardiovascular and renal actions of vitamin $\mathrm{D}$ and estrogen. Front Biosci (Scholar edition) 2013;5: 134-48. DOI: $10.2741 / \mathrm{s} 362$.

3. Deluca HF, Cantorna MT. Vitamin D: its role and uses in immunology. FASEB J 2001; I 5(I 4):2579-85. DOI: 10.1096/fj.0I-0433rev.

4. Tang BM, Eslick GD, Nowson C, Smith C, Bensoussan A. Use of calcium or calcium in combination with vitamin D supplementation to prevent fractures and bone loss in people aged 50 years and older: a meta-analysis. Lancet 2007;370 (9588):657-66. DOI: 10.1016/50140-6736(07)61342-7.

5. Feldman D, Krishnan AV, Swami S, Giovannucci E, Feldman BJ. The role of vitamin $D$ in reducing cancer risk and progression. Nat Rev Cancer 20I4; I4(5):342. DOI: 10.1038/nrc 3691

6. Pleskacova A, Bartakova V, Pacal L, Kuricova K. Vitamin D Status in Women with Gestational Diabetes
Mellitus during Pregnancy and Postpartum. Biomed Res Int 20I5;2015:260624. DOI: 10.1155/ 2015/260624.

7. Holick MF. Resurrection of vitamin D deficiency and rickets. J Clin Invest 2006; I I 6(8):2062-72. DOI: 10.1 I72/JCl29449

8. Bailey RL, West Jr KP, Black RE. The Epidemiology of Global Micronutrient Deficiencies. Ann Nutr Metab 2015;66(Suppl. 2):22-33. DOI: 10.1159/000371618

9. Elmadfa I, Meyer AL. Vitamins for the first 1000 days: preparing for life. Int J Vitam Nutr Res 2012;82(5):342-7. DOI: 10. I024/0300-983 I/a000I 29

10. Trumbo P, Yates AA, Schlicker S, Poos $M$. Dietary reference intakes: vitamin A, vitamin $\mathrm{K}$, arsenic, boron, chromium, copper, iodine, iron, manganese, molybdenum, nickel, silicon, vanadium, and zinc. J Am Diet Assoc 200I;I0I(3):294-30I. DOI: 10.1016/S0002-8223(0I)00078-5

I I. Khan H, Ansari M, Waheed U, Farooq $N$. Prevalence of vitamin $D$ deficiency in general population of Islamabad, Pakistan. Ann Pak Inst Med Sci 2013;9(I):45-7.

12. Pfotenhauer KM, Shubrook JH. Vitamin D Deficiency, Its Role in Health and Disease, and Current Supplementation Recommendations. J Am Osteopath Assoc 2017;117(5): 30I-5. DOI: 10.7556/jaoa.20I7.055.

13. Cashman KD, Sheehy T, O'Neill CM. Is vitamin $D$ deficiency a public health concern for low middle income countries? A systematic literature review. Eur J Nutr 2019;58(I):433-53. DOI: I0. I007/s00394-018-1607-3.

14. Krishnaveni GV, Veena SR, Winder NR, Hill JC, Noonan K, Boucher BJ, et al. Maternal vitamin $D$ status during pregnancy and body composition and cardiovascular risk markers in Indian children: the Mysore Parthenon Studyl-4. Am J Clin Nutr 20II;93(3):628-35. DOI: 10.3945/ ajcn. I I0.00392I.

15. Zaman S, Hawlader M, Biswas A, Hasan M, Jahan M, Ahsan G. High Prevalence of Vitamin D Deficiency among Bangladeshi Children: An Emerging Public Health Problem. Health 20I7;09:1680-8. DOI: 10.4236/health.2017.912123

16. World Health Organization (WHO), 
Food and Agriculture Organization (FAO). National Nutrition and Food Security Survey, Afghanistan. 2013. [Cited on: January 15, 2019]. Available from URL: http://www.fao. org/3/aat6।7e.pdf

17. Bhutta Za, Soofi SB, Zaidi SSH, Habib A, Hussain I. Pakistan National Nutrition Survey, 20II. Department of Paediatrics and Child Health, The Agha Khan University, Pakistan. 20II [Cited on: January 15, 2019]. Available from URL: https://ecommons.aku. edu/cgi/viewcontent.cgi? article = I 262\&context = pakistan_fhs_mc_wo men_childhealth_paediatr

18. Riaz H, Finlayson AE, Bashir S, Hussain $S$, Mahmood S, Malik F, et al. Prevalence of Vitamin D deficiency in Pakistan and implications for the future. Expert Rev Clin Pharmacol 20I6;9(2):329-38. DOI: 10.1586/ I75|2433.20I6.|I225I9.

19. lqbal R, Jafri L, Haroon A, Habib Khan A. Illuminating the dark side--vitamin D status in different localities of Karachi. J Coll Physicians Surg Pak 20I3;23(8):604-6. DOI: 08.20I3/ JCPSP.604606.

20. Lundqvist A, Sandström H, Stenlund H, Johansson I, Hultdin J. Vitamin D Status during Pregnancy: A Longitudinal Study in Swedish Women from Early Pregnancy to Seven Months Postpartum. PLoS One 20I6; II(3):e0I50385. DOI: 10. |37|/journal.pone.0I50385.
21. Aji AS, Erwinda E, Yusrawati Y, Malik SG, Lipoeto NI. Vitamin D deficiency status and its related risk factors during early pregnancy: a cross-sectional study of pregnant Minangkabau women, Indonesia. BMC Pregnancy Childbirth 2019;19(I): I83. DOI: I0. I |86/s I 2884-0|9-234 I-4.

22. Mulligan ML, Felton SK, Riek AE, Bernal-Mizrachi C. Implications of vitamin $D$ deficiency in pregnancy and lactation. Am J Obstet Gynecol 20I 0;202(5):e429I-e4299. DOI: 10.1016/j.ajog. 2009.09.002.

23. Lyu LC, Hsu YN, Chen HF, Lo CC, Lin CL. Comparisons of four dietary assessment methods during pregnancy in Taiwanese women. Taiwan J Obstet Gynecol 2014;53 (2): I62-9. DOI: I0.1016/j.tjog. 2014.04.007.

24. Lomonte C, Antonelli M, Vernaglione L, Cazzato F, Casucci F, Chimienti D, et al. Are low plasma levels of 25$(\mathrm{OH})$ vitamin $\mathrm{D}$ a major risk factor for hyperparathyroidism independent of calcitriol in renal transplant patients? J Nephrol 2005; 18(I):96-I0I.

25. Dawodu A, Wagner CL. Prevention of vitamin $D$ deficiency in mothers and infants worldwide - a paradigm shift. Paediatrics and international child health. Paediatr Int Child Health 2012;32(I):3-I3. DOI: I0. | | 79/| 465328| | |Y.0000000024

26. Khalessi N, Kalani M, Araghi M, Farahani Z. The Relationship between
Maternal Vitamin D Deficiency and Low Birth Weight Neonates. J Family Reprod Health 20 I 5;9(3): I I3-7.

27. Sharma N, Nath C, Mohammad J. Vitamin $\mathrm{D}$ status in pregnant women visiting a tertiary care center of North Eastern India. J Family Med Prim Care 2019;8(2): 356-60. DOI: $10.4103 /$ jfmpc.jfmpc_404_I8.

28. Sohail S, Rashid S. Serum 25 hydroxy vitamin-D level is the best predictor of vitamin-D deficiency during pregnancy. Professional Med J 2013(I):78-8I.

29. Sharif S, Farasat T, Shoaib H, Saqib M, Fazal S. Vitamin D levels among pregnant and lactating women. J Coll Physicians Surg Pak 20 I 3;23 (I2):8625. DOI: I2.2013/JCPSP. 862865.

30. Roomi MA, Farooq A, Ullah E, Lone KP. Hypovitaminosis $D$ and its association with lifestyle factors. Pak J Med Sci 20। 5;3। (5): I 236-40. DOI: 10.12669/pjms.315.7196

31. Duchaine CS, Diorio C. Association between intake of sugar-sweetened beverages and circulating 25hydroxyvitamin $D$ concentration among premenopausal women. Nutrients 2014;6(8):2987-99. DOI: 10.3390/nu6082987

32. Mahmood K, Akhtar ST, Talib A, Haider I. Vitamin D status in a population of healthy adults in Pakistan. Pak J Med Sci 2009;25(4):545-50.

\section{AUTHORS' CONTRIBUTIONS}

Following authors have made substantial contributions to the manuscript as under:

BS: Acquisition, analysis and interpretation of data, drafting the manuscript, final approval of the version to be published

MS: Study design, analysis and interpretation of data, drafting the manuscript, critical review, final approval of the version to be published

MJK: Conception and study design, Acquisition, analysis and interpretation of data, drafting the manuscript, final approval of the version to be published

SK \& HB: Acquisition of data, drafting the manuscript, final approval of the version to be published

Authors agree to be accountable for all aspects of the work in ensuring that questions related to the accuracy or integrity ofany part of the work are appropriately investigated and resolved.

\begin{tabular}{c} 
CONFLICT OF INTEREST \\
Authors declared no conflict of interest \\
GRANT SUPPORT AND FINANCIAL DISCLOSURE \\
Partially supported by research grant to first author from ORIC, KMU, Peshawar, Pakistan. \\
\hline
\end{tabular}

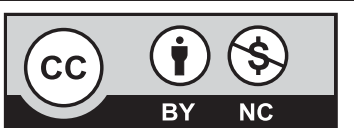

This is an Open Access article distributed under the terms of the Creative Commons Attribution-Non Commercial 2.0 Generic License. 